\title{
Expression of Toll-Like Receptor-2 and -4 in Amniochorion Membranes of Preterm Delivery in the Presence of Histologic Chorioamnionitis
}

\author{
Natália Prearo Moço1, Laura Fernandes Martin1, Jossimara Polettini'1, \\ Ana Carolina Pereira1, José Carlos Peraçoli², Márcia Guimarães da Silva ${ }^{{ }^{*}}$ \\ ${ }^{1}$ Department of Pathology, Botucatu Medical School (FMB), São Paulo State University (UNESP), Botucatu, \\ Brazil \\ ${ }^{2}$ Department of Gynecology and Obstetrics, Botucatu Medical School (FMB), São Paulo State University \\ (UNESP), Botucatu, Brazil \\ Email: $\underline{\text { mgsilva@fmb.unesp.br }}$
}

Received 24 July 2014; revised 18 August 2014; accepted 15 September 2014

Copyright (C) 2014 by authors and Scientific Research Publishing Inc.

This work is licensed under the Creative Commons Attribution International License (CC BY). http://creativecommons.org/licenses/by/4.0/

(c) (i) Open Access

\section{Abstract}

Expression of Toll-like receptors at the maternal-fetal interface during normal and complicated pregnancies has aroused interest in the last few years. However, despite the importance of TLR-2 and TLR-4, which recognizes most microorganisms presenting in the amniotic cavity infections associated with prematurity, comparison of the expressions of these receptors is rare in the literature. Thus, the purpose of this study was to compare the gene expression between TLR-2 and TLR-4 in amniochorion membranes of pregnant women with preterm delivery in the presence of histologic chorioamnionitis (HCA). Amniochorion membranes were collected from 40 pregnant women with preterm delivery; 20 presented HCA and 20 did not. Fragments of the membranes were submitted to total RNA extraction, followed by cDNA production by reverse transcription. Real time quantitative PCR was used to quantify the gene expression of the TLRs. mRNA concentrations between TLR-2 and TLR-4 were compared using the nonparametric Mann-Whitney test. TLR-2 expression was higher than TLR-4 expression in the presence of HCA. No difference was observed between TLR-2 and TLR-4 expression in membranes in the absence of inflammatory infiltrate. In conclusion, amniochorion membranes express TLR-2 and TLR-4 and higher TLR-2 expression in the presence of histologic chorioamnionitis suggests that microorganisms recognizable by TLR-2 play an important role in the physiopathology of preterm labor.

${ }^{*}$ Corresponding author.

How to cite this paper: Moço, N.P., Martin, L.F., Polettini, J., Pereira, A.C., Peraçoli, J.C. and da Silva, M.G. (2014) Expression of Toll-Like Receptor-2 and -4 in Amniochorion Membranes of Preterm Delivery in the Presence of Histologic Chorioamnionitis. Open Journal of Obstetrics and Gynecology, 4, 857-863. http://dx.doi.org/10.4236/ojog.2014.414120 


\section{Keywords}

\section{Preterm Labor, Pregnancy Complications, Innate Immunology, TLR-2, TLR-4}

\section{Introduction}

The amniochorion membranes are a complex multilaminated structure of great importance for fetal development. One of the functions proposed for this structure is the role of an immunological barrier against pathogenic microorganisms that ascend from the lower genital tract, since these tissues express antimicrobial agents, such as human beta defensins (HBDs) [1] [2], cytokines [3] [4] and other components of the innate immune system, including Toll-like receptors (TLRs) [5].

TLRs are transmembrane receptors that recognize several pathogen-associated molecular patterns (PAMPs) and stimulate proinflammatory cytokine gene transcription [6] [7]. Activation of TLR by their specific ligand culminates in the activation of transcription factors, most prominently NF- $\kappa \mathrm{B}$, which is involved in regulating the synthesis of proinflammatory cytokines and prostaglandins [8]. TLR-2 recognizes the widest spectrum of microbial components, including peptidoglycan and lipoteichoic acid from Gram positive bacteria [9] [10], lipoproteins from Gram-negative bacteria [11], mycoplasms [12] and fungal zymosan [13]. The broad specificity of TLR-2 is due to its ability to act both as a homodimer and as a heterodimer with TLR-1 and TLR-6 [14]. TLR-4 has been genetically identified as a mediator of lipopolysaccharide (LPS)-induced signal transduction [6] [15].

Several studies have associated intraamniotic infection and the maternal inflammatory response with early activation of the parturition pathway [16]-[19]. Bacteria from the lower genital tract can access the amniochorion membranes by ascending the cervical canal, and subsequently infect the amniotic cavity [20]. This fact is evidenced by the finding that large number of bacteria identified in the amniotic cavity of preterm pregnancies reside in the lower genital tract, including the species associated with bacterial vaginosis (BV) [21]-[23].

The presence of several bacterial species in the lower genital tract and consequently in intraamniotic infection, provides different types of PAMPs, which justifies the expression of several TLRs at the maternal-fetal interface, especially in the presence of histologic chorioamnionitis (HCA), defined as infiltration of fetal membranes by polymorphonuclear leukocytes. Kim et al. [5] reported that term and preterm spontaneous labor with histologic chorioamnionitis were associated with an increased expression of TLR-2 and TLR-4 in the membranes. Kumazaki et al. [24] showed that TLR-4 expression was detected in Houfbauer cells within the villi of term and preterm placenta and the immunoreactivity was higher in preterm placenta in the presence of histologic chorioamnionitis.

TLR-2 and TLR-4 recognize the majority of the microorganisms involved in amniotic cavity infections that which are involved in activating the inflammatory response in amniochorion membranes. Despite the importance of these receptors, comparison between expression of TLR-2 and TLR-4 in amniochorion membranes is rare in literature. This comparison may contribute to understanding the role of innate immunity at the fetal-maternal interface in pregnancies complicated by prematurity and HCA.

The purpose of this study was to compare the gene expression between TLR-2 and TLR-4 in amniochorion membranes from preterm delivery, considering the status of histologic chorioamnionitis.

\section{Methods}

\subsection{Study Population}

A cross-sectional study was conducted in Obstetric Unit, Botucatu Medical School, São Paulo State University, Brazil and in the Laboratory of Immunopathology of the Maternal-Fetal Relationship, Department of Pathology, Botucatu Medical School, São Paulo State University, UNESP, from 2009 to 2011.

The study group consisted of 40 pregnant women with preterm delivery. A total of 20 amniochorion membranes presented HCA and in 20 the inflammatory infiltrate was absent. Gestational age was calculated from the first day of last menstrual period and/or by first-trimester ultrasound examination. The pregnant women were 
not eligible if they presented multiple pregnancies, diabetes, hypertension, fetal anomalies, placental abruption, placenta previa, intrauterine growth restriction and urinary tract infection. We excluded of this study pregnant women whose the quality and concentration of extracted total RNA of the amniochorion membranes were poor for this technique. The demographic and clinical characteristics of the study population were obtained from medical records.

This study was approved by the Research Ethics Committee of Botucatu Medical School, São Paulo State University (Protocol 3170-2009), and written informed consent was obtained from all participants.

\subsection{Collection of Amniochorion Membranes}

All collect amniochorion membranes were stored in RNA later ${ }^{\circledR}$ solution (Ambion-Austin, TX, USA) at a concentration of $10 \mu \mathrm{l} / \mathrm{mg}$ of tissue at $-80^{\circ} \mathrm{C}$. Samples of the membranes were fixed in $10 \%$ formalin, embedded in paraffin, sectioned and stained with hematoxylin and eosin for histopathological analyses. Histologic chorioamnionitis was diagnosed by the presence of neutrophilic infiltration in amniochorion membranes, as described Yoon et al. [25].

\subsection{Real Time PCR}

TLR-2 and TLR-4 expression were measure by real time quantitative PCR with an ABI Prism ${ }^{\circledR} 7300$ Sequence Detector (Applied Biosystems ${ }^{\circledR}$, Foster City, CA, USA). Total RNA was extracted from amniochorion membranes samples using an IllustraRNAspin Mini Isolation Kit (GE Healthcare ${ }^{\circledR}$, Pittsburgh, PA, USA). To preclude genomic DNA contamination, all RNA samples were treated with RNase-free DNAse I (New England Biolabs $^{\circledR}$, Ipswich, MA, USA) before amplification. The quality and concentration of extracted total RNA were measured with Epoch (Biotek ${ }^{\circledR}$, Winnosk, VT, USA) by determining the absorbance ratio $260 \mathrm{~nm} / 280 \mathrm{~nm}$ and absorbance at $260 \mathrm{~nm}$, respectively. RNA $(0.1 \mu \mathrm{g} / \mu \mathrm{L})$ was submitted to reverse transcription using the HighCapacity cDNA Archive Kit, following the manufacturer's instructions (Applied Biosystems, Foster City, CA, USA). TaqMan-validated primers and TaqMan MGB probes were used to amplify TLR-2 (Hs00610101_m1) and TLR-4 (Hs00370853_m1). The levels of expression of the TLRs in each sample were normalized with the TBP (TATA box binding protein, ID Hs99999910_m1) housekeeping gene [26]. Amplification was performed using the Line Gene K (Bioer ${ }^{\circledR}$ ) using the ddCT method [27]. Thermal cycling was initiated with a denaturating step of $10 \mathrm{~min}$ at $95^{\circ} \mathrm{C}$, followed by 40 cycles of $95^{\circ} \mathrm{C}$ for $15 \mathrm{~s}$ and $60^{\circ} \mathrm{C}$ for $1 \mathrm{~min}$. All reactions were performed in duplicate, and negative controls were included in each run.

Statistical analyses were performed with Sigma Stat Software version 3.1. After checking for data normality (Kolmogorov-Smirnov test with Lilliefors' correction), TLR-2 and TLR-4 mRNA concentrations were compared using the nonparametric Mann-Whitney test. The categorical variables marital status, ethnicity and type of delivery were compared using Fisher's exact test. Maternal age was compared using the $t$ test and gestational age at delivery was compared using the Mann-Whitney test. In all tests, the significance level was set at $p$ value $<0.05$.

\section{Results}

\subsection{Sociodemographic and Obstetrics Characteristics}

The demographic and clinical characteristics of the study population are summarized in Table 1. Maternal age, ethnicity, type of delivery and parity were similar between the groups. Similar gestational age at delivery was observed independently of histologic chorioamnionitis status.

\subsection{Relative Quantification of TLR-2 and TLR-4}

\section{Comparison between TLR-2 and TLR-4 Expression in Amniochorion Membranes}

The relative quantification of TLR-2 and TLR-4 mRNA in amniochorion membranes are shown in Figures 1-3. All amniochorion membranes included in the study expressed TLR-2 and TLR-4 mRNA. TLR-2 expression [3.87 (0.46 - 47.38)] was higher than TLR-4 expression [0.50 (0.028 - 18.05)] in the presence of histologic chorioamnionitis $(p<0.001$ ) (Figure 2$)$. No difference was observed between TLR-2 and TLR-4 expression in membranes in the absence of inflammatory infiltrate (Figure 3). 
Table 1. Demographics and obstetric characteristics of the pregnant women included in this study.

\begin{tabular}{|c|c|c|c|}
\hline Characteristics & $\begin{array}{l}\text { Preterm delivery without HCA } \\
\qquad(\mathrm{n}=20)\end{array}$ & $\begin{array}{l}\text { Preterm delivery with HCA } \\
\qquad(\mathrm{n}=20)\end{array}$ & $p$-value \\
\hline Maternal age ${ }^{*}$ & $24.55 \pm 6.47$ & $22.10 \pm 5.99$ & 0.222 \\
\hline \multicolumn{4}{|l|}{ Marital status } \\
\hline Single & $27.78 \%(5 / 18)$ & $40 \%(8 / 20)$ & \multirow{2}{*}{0.506} \\
\hline Married & $72.22 \%(13 / 18)$ & $60 \%(12 / 20)$ & \\
\hline \multicolumn{4}{|l|}{ Ethnicity } \\
\hline White & $95 \%(19 / 20)$ & $85 \%(17 / 20)$ & \multirow{2}{*}{0.605} \\
\hline Non-white & $5 \%(1 / 20)$ & $15 \%(3 / 20)$ & \\
\hline \multicolumn{4}{|l|}{ Type of delivery } \\
\hline Vaginal & $75 \%(15 / 20)$ & $60 \%(12 / 20)$ & \multirow{2}{*}{0.501} \\
\hline Cesarean & $25 \%(5 / 20)$ & $40 \%(8 / 20)$ & \\
\hline Gestational age at delivery (days) $^{+}$ & $238.5(177-258)$ & $233(182-255)$ & 0.715 \\
\hline
\end{tabular}

*Values expressed as mean $\pm \mathrm{SD}$; ${ }^{+}$Values expressed as median (min-max); HCA: histologic chorioamnionitis.

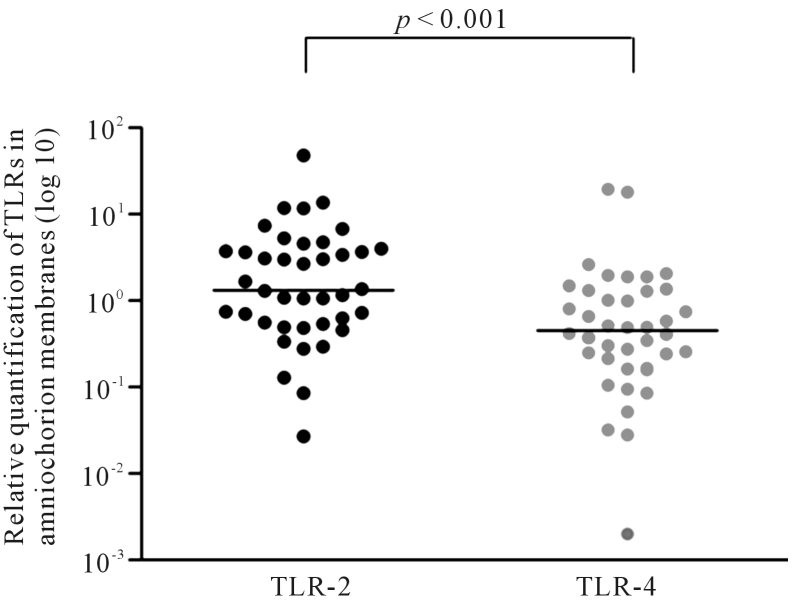

Figure 1. Relative quantification of TLR-2 and TLR-4 in all amniochorion membranes analyzed. Mann-Whitney test.

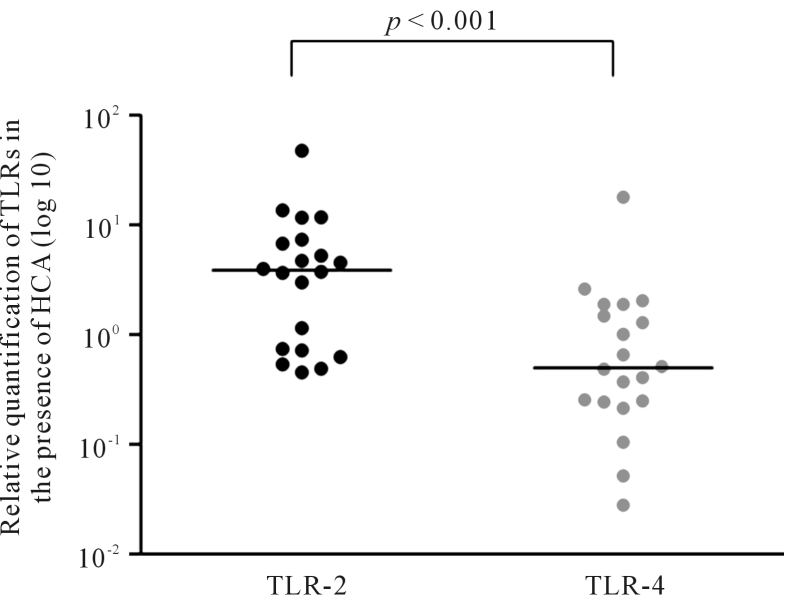

Figure 2. Relative quantification of TLR-2 and TLR-4 in amniochorion membranes in the presence of HCA. MannWhitney test. HCA: histologic chorioamnionitis. 


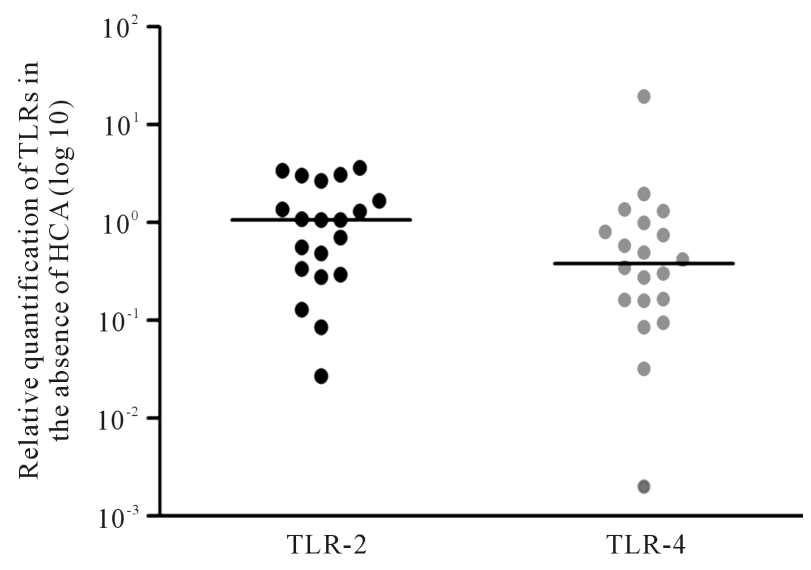

Figure 3. Relative quantification of TLR-2 and TLR-4 in amniochorion membranes in the absence of HCA. MannWhitney test. HCA: histologic chorioamnionitis.

\section{Discussion}

The function of amniochorion membranes as an immunological barrier, especially concerning the expression of components of the innate immune system, such as TLRs and antimicrobial agents, ensures the proper development of the pregnancy by promoting allograft tolerance while maintaining the maternal immune response against pathogens [1] [5] [24].

TLR-2 is one of the more promiscuous TLRs, and is able to recognize a broad spectrum of PAMPs, since activation can occur concomitantly with TLR-1 and TLR-6 [28] [29]. The TLR-1/TLR-2 heterodimer recognizes triacylated lipopeptides from Gram-negative bacteria and mycoplasma, whereas the TLR-2/TLR-6 heterodimer recognizes diacylated lipopeptides from Gram-positive bacteria and mycoplasma [28] [29]. TLR-4 recognizes the LPS of Gram-negative bacteria [30], including those found in bacterial vaginosis (BV), such as Bacteroides spp., Fusobacterium spp. and Prevotella [31] [32].

This study demonstrated gene expression of TLR-2 in the amniochorion membranes was significantly higher thanTLR-4 gene expression in the presence of histologic chorioamnionitis, which results from microbial invasion of the amniotic cavity [33]. Comparison of amniochorion membranes in the absence of inflammatory infiltrate showed no significant differences.

Romero et al. [34] demonstrated that the most frequent microorganisms present in the amniotic cavity of preterm pregnancies are Mycoplasma hominis and Ureaplasma urealyticum, and theses possess molecular patterns recognizable by the TLR-1/TLR-2 heterodimer. In a recent study conducted in our laboratory, Marconi et al. [23] reported polymicrobial infection of the amniotic cavity of pregnant women in preterm labor, with a higher prevalence of Mycoplasma hominis and Ureaplasma urealyticum, however other species were also detected including Leptotrichia amnionii, Bacteroides fragilis and Prevotella bivia, which are recognizable by TLR-4.

Our results suggest that the expression of TLR-2 in amniochorion membranes with histologic chorioamnionitisis enhanced by modulation of the inflammatory response triggered by PAMPs that are recognized by this receptor. Additionally, TLR-4 activation by Gram-negative bacteria can enhance the expression of TLR-2 in a time-dependent manner. Studies have been showed that early LPS recognition by TLR-4 upregulates TLR-2 expression in epithelial cells, resulting in a delayed TLR-2 response [35]-[38]. These late TLR-2 upregulation via TLR-4 could explain our results that showing only delayed TLR-2 response was detected, a fact supported by a diagnosis of histologic chorioamnionitis, since this is a final stage of microbial invasion of amniotic cavity. This study has a limitation regarding the lack of the histologic chorioamnionitis grade analysis once the small sample size did not allowed these groups subdivision. An intense inflammatory infiltrate can trigger higher TLRs expression compared to discrete histologic chorioamnionitis, but this aspect needs further analysis.

\section{Conclusion}

In conclusion, this study showed that amniochorion membranes express TLR-2 and TLR-4 and that the expression of TLR-2 is higher than TLR-4 in the amniochorion membranes from preterm pregnancies in the presence 
of histologic chorioamnionitis. This result supports the understanding that microorganisms recognizable by TLR-2 play an important role in the physiopathology of preterm delivery.

\section{Source of Support}

São Paulo Research Foundation (Fapesp); grants numbers 2008/55418-1 and 2008/53382-0.

\section{References}

[1] King, A.E., Paltoo, A., Kelly, R.W., et al. (2007) Expression of Natural Antimicrobials by Human Placenta and Fetal Membranes. Placenta, 28, 161-169. http://dx.doi.org/10.1016/j.placenta.2006.01.006

[2] Polettini, J., Takitane, J., Peraçoli, J.C. and Silva, M.G. (2011) Expression of $\beta$ Defensins 1,3 and 4 in Chorioamniotic Membranes of Preterm Pregnancies Complicated by Chorioamnionitis. European Journal of Obstetrics \& Gynecology and Reproductive Biology, 157, 150-155. http://dx.doi.org/10.1016/j.ejogrb.2011.03.014

[3] Polettini, J., Peraçoli, J.C., Candeias, J.M.G., Araújo Júnior, J.P. and Silva, M.G. (2009) Inflammatory Cytokine mRNA Detection by Real Time PCR in Chorioamniotic Membranes from Pregnant Women with Preterm Premature Rupture of Membranes. European Journal of Obstetrics \& Gynecology and Reproductive Biology, 144, 27-33. http://dx.doi.org/10.1016/j.ejogrb.2009.01.008

[4] Zaga-Clavellina, V., Garcia-Lopez, G., Flores-Herrera, H., Espejel-Nuñez, A., Flores-Pliego, A., Soriano-Becerrio, D., Maida-Claros, R., Merchant-Larios, H. and Vadillo-Ortega, F. (2007) In Vitro Secretion Profiles of Interlukin (IL)-1 Beta, IL-6, Il-8, IL-10 and TNF-Alpha after Selective Infection with Escherichia coli in Human Fetal Membranes. Reproductive Biology and Endocrinology, 13, 5-46.

[5] Kim, Y.M., Romero, R., Chaiworapongsa, T., et al. (2004) Toll-Like Receptor-2 and -4 in the Chorioamniotic Membranes in Spontaneous Labor at Term and in Preterm Parturition That Are Associated with Chorioamnionitis. American Journal of Obstetrics Gynecology, 191, 1346-1355. http://dx.doi.org/10.1016/j.ajog.2004.07.009

[6] Akira, S., Takeda, K. and Kaisho, T. (2001) Toll-Like Receptors: Critical Proteins Linking Innate and Acquired Immunity. Nature Immunology, 2, 675-680. http://dx.doi.org/10.1038/90609

[7] Aderem, A. and Ulevitch, R.J. (2000) Toll-Like Receptors in the Induction of the Innate Immune Response. Nature, 406, 782-787. http://dx.doi.org/10.1038/35021228

[8] Abbas, A.K. and Lichtman, A.H. (2005) Imunologia celular e molecular. 5th Edition, Elsevier, Rio de Janeiro.

[9] Abreu, M., Fukata, M. and Arditi, M. (2005) TLR Signaling in the Gut in Health and Disease. The Journal of Immunology, 174, 4453-4460. http://dx.doi.org/10.4049/jimmunol.174.8.4453

[10] Fazeli, A., Bruce, C. and Anumba, D. (2005) Characterization of Toll-Like Receptors in the Female Reproductive Tract in Humans. Human Reproduction, 20, 1372-1378. http://dx.doi.org/10.1093/humrep/deh775

[11] Beijar, E.C., Mallard, C. and Powell, T.L. (2006) Expression and Subcellular Localization of TLR-4 in Term and First Trimester Human Placenta. Placenta, 27, 322-326. http://dx.doi.org/10.1016/j.placenta.2004.12.012

[12] Schwandner, R., Dziarski, R., Wesche, H., Rothe, M. and Kirschning, C. (1999) Peptidoglycan- and Lipoteichoic AcidInduced Cell Activation Is Mediates by Toll-Like Receptor 2. Journal of Biological Chemistry, 274, 17406-17409. http://dx.doi.org/10.1074/jbc.274.25.17406

[13] Yoshimura, A., Lien, E., Ingalls, R., Tuomanen, E., Dziarski, R. and Golenbock, D. (1999) Cutting Edge: Recognition of Gram-Positive Bacterial Cell Wall Components by the Innate Immune System Occurs via Toll-Like Receptor 2. Journal of Immunology, 163, 1-5.

[14] Takeda, K., Kaisho, T. and Akira, S. (2003) Toll-Like Receptors. Annual Review of Immunology, 21, 335-376. http://dx.doi.org/10.1146/annurev.immunol.21.120601.141126

[15] Underhill, D., Ozinsky, A., Hajjar, A., Stevens, A., Wilson, C.B., Bassetti, M. and Aderem, A. (1999) The Toll-Like Receptor 2 Is Recruited to Macrophage Phagosomes and Discriminates between Pathogens. Nature, 401, 811-815. http://dx.doi.org/10.1038/44605

[16] DiGiulio, D.B., Romero, R., Amogan, H.P., Kusanovic, J.P., Bik, E.M., Gotsch, F., et al. (2008) Microbial Prevalence, Diversity and Abundance in Amniotic Fluid during Preterm Labor: A Molecular and Culture-Based Investigation. PLoS ONE, 3, e3056. http://dx.doi.org/10.1371/journal.pone.0003056

[17] Nguyen, D.P., Gerber, S., Hohlfeld, P., Sandrine, G. and Witkin, S.S. (2004) Mycoplasma Hominis in Mid-Trimester Amniotic Fluid: Relation to Pregnancy Outcome. Journal of Perinatal Medicine, 32, 323-326. http://dx.doi.org/10.1515/JPM.2004.060

[18] Perni, S.C., Vardhana, S., Korneeva, I., Tuttle, S.L., Paraskevas, L.R., Chasen, S.T., Kalish, R.B. and Witkin, S.S. (2004) Mycoplasma hominis and Ureaplasma urealyticum in Midtrimester Amniotic Fluid: Association with Amniotic Fluid Cytokine Levels and Pregnancy Outcome. American Journal of Obstetrics \& Gynecology, 191, 1382-1386. 
http://dx.doi.org/10.1016/j.ajog.2004.05.070

[19] Yoon, B.H., Romero, R., Lim, J.H., Shim, S.S., Hong, J.S., Shim, J.Y. and Jun, J.K. (2003) The Clinical Significance of Detecting Ureaplasma urealyticum by the Polymerase Chain Reaction in the Amniotic Fluid of Patients with Preterm Labor. American Journal of Obstetrics \& Gynecology, 189, 919-924. http://dx.doi.org/10.1067/S0002-9378(03)00839-1

[20] Kim, M.J., Romero, R., Gervasi, M.T., Kim, J.S., Yoo, W., Lee, D.C., et al. (2009) Widespread Microbial Invasion of the Chorioamniotic Membranes Is a Consequence and Not a Cause of Intra-Amniotic Infection. Laboratory Investigation, 89, 924-936. http://dx.doi.org/10.1038/labinvest.2009.49

[21] Jones, H.E., Harris, K.A., Azizia, M., Bank, L., Carpenter, B., Hartley, J.C., Klein, N. and Peebles, D. (2009) Differing Prevalence and Diversity of Bacterial Species in Fetal Membranes from Very Preterm and Term Labor. PLoS ONE, 4, e8205. http://dx.doi.org/10.1371/journal.pone.0008205

[22] Donders, G.G., Van Calsteren, K., Bellen, G., Reybrouck, R., Van den Bosch, T., Riphagen, I. and Van Lierde, S. (2009) Predictive Value for Preterm Birth of Abnormal Vaginal Flora, Bacterial Vaginosis and Aerobic Vaginitis during the First Trimester of Pregnancy. BJOG: An International Journal of Obstetrics \& Gynaecology, 116, 1315-1324. http://dx.doi.org/10.1111/j.1471-0528.2009.02237.x

[23] Marconi, C., de Andrade Ramos, B.R., Peraçoli, J.C., Donders, G.G. and da Silva, M.G. (2011) Amniotic Fluid Interleukin-1 Beta and Interleukin-6, but Not Interleukin-8 Correlate with Microbial Invasion of the Amniotic Cavity in Preterm Labor. American Journal of Reproductive Immunology, 65, 549-556. http://dx.doi.org/10.1111/j.1600-0897.2010.00940.x

[24] Kumazaki, K., Nakayama, M., Yanagihara, I., Suehara, N. and Wada, Y. (2004) Immunohistochemical Distribution of Toll-Like Receptor 4 in Term and Preterm Human Placentas from Normal and Complicated Pregnancy Including Chorioamnionitis. Human Pathology, 35, 47-54. http://dx.doi.org/10.1016/j.humpath.2003.08.027

[25] Yoon, B.H., Romero, R., Kim, C.J., Jun, J.K., Gomez, R., Choi, J.H. and Syu, H.C. (1995) Amniotic Fluid Interleukin-6: A Sensitive Test for Antenatal Diagnosis of Acute Inflammatory Lesions of Preterm Placenta and Prediction of Perinatal Morbidity. American Journal of Obstetrics \& Gynecology, 172, 960-970. http://dx.doi.org/10.1016/0002-9378(95)90028-4

[26] Maier, T., Guell, M. and Serrano, L. (2009) Correlation of mRNA and Protein in Complex Biological Samples. FEBS Letters, 583, 3966-3973. http://dx.doi.org/10.1016/j.febslet.2009.10.036

[27] Livak, K.J. and Schmittgen, T.D. (2001) Analysis of Relative Gene Expression Data Using Real-Time Quantitative PCR and the 2(-Delta Delta C(T)) Method. Methods, 25, 402-408. http://dx.doi.org/10.1006/meth.2001.1262

[28] Kawai, T. and Akira, S. (2010) The Role of Pattern-Recognition Receptor in Innate Immunity: Update of Toll-Like Receptors. Nature Immunology, 11, 373-384. http://dx.doi.org/10.1038/ni.1863

[29] Takeuchi, O., Sato, S., Horiuchi, T., Hoshino, K., Takeda, K., Dong, Z., et al. (2002) Cutting Edge: Role of Toll-Like Receptor 1 in Mediating Immune Response to Microbial Lipoproteins. Journal of Immunology, 169, 10-14. http://dx.doi.org/10.4049/jimmunol.169.1.10

[30] Akira, S. (2003) Mammalian Toll-Like Receptors. Current Opinion in Immunology, 15, 5-11. http://dx.doi.org/10.1016/S0952-7915(02)00013-4

[31] Forsum, U., Holst, E., Larsson, P.G., Vasquez, A., Jakobsson, T. and Mattsby-Baltzer, I. (2005) Bacterial Vaginosis—A Microbiological and Immunological Enigma. APMIS, 113, 81-90. http://dx.doi.org/10.1111/j.1600-0463.2005.apm1130201.x

[32] Yudin, M.H. (2005) Bacterial Vaginosis in Pregnancy: Diagnosis, Screening and Management. Clinics in Perinatology, 32, 617-627. http://dx.doi.org/10.1016/j.clp.2005.05.007

[33] Fahey, J.O. (2008) Clinical Management of Intra-Amniotic Infection and Chorioamnionitis: A Review of the Literature. Journal of Midwifery \& Women's Health, 53, 227-235. http://dx.doi.org/10.1016/j.jmwh.2008.01.001

[34] Romero, R., Espinoza, J., Gonçalvez, L.F., Kusanovic, J.P., Friel, L.A. and Nien, J.K. (2006) Inflammation in Preterm and Term Labour and Delivery. Seminars in Fetal and Neonatal Medicine, 11, 317-326. http://dx.doi.org/10.1016/j.siny.2006.05.001

[35] Uno, K., Kato, K., Atsumi, T., Suzuki, T., Yoshitake, J., Morita, H., et al. (2007) Toll-Like Receptor (TLR) 2 Induced through TLR4 Signaling Initiated by Helicobacter Pylori Cooperatively Amplifies iNOS Induction in Gastric Epithelial Cells. American Journal of Physiology-Gastrointestinal and Liver Physiology, 293, G1004-G1012. http://dx.doi.org/10.1152/ajpgi.00096.2007

[36] Weiss, D.S., Raupach, B., Takeda, K., Akira, S. and Zychlinsky, A. (2004) Toll-Like Receptors Are Temporally Involved in Host Defense. Journal of Immunology, 172, 4463-4469. http://dx.doi.org/10.4049/jimmunol.172.7.4463

[37] Fan, J., Frey, R.S. and Malik, A.B. (2003) TLR4 Signaling Induces TLR2 Expression in Endothelial Cells via Neutrophil NADPH Oxidase. Journal of Clinical Investigation, 112, 1234-1243. http://dx.doi.org/10.1172/JCI18696

[38] Lorenz, E. (2006) TLR2 and TLR4 Expression during Bacterial Infections. Current Pharmaceutical Design, 12, 41854193. http://dx.doi.org/10.2174/138161206778743547 
Scientific Research Publishing (SCIRP) is one of the largest Open Access journal publishers. It is currently publishing more than 200 open access, online, peer-reviewed journals covering a wide range of academic disciplines. SCIRP serves the worldwide academic communities and contributes to the progress and application of science with its publication.

Other selected journals from SCIRP are listed as below. Submit your manuscript to us via either submit@scirp.org or Online Submission Portal.
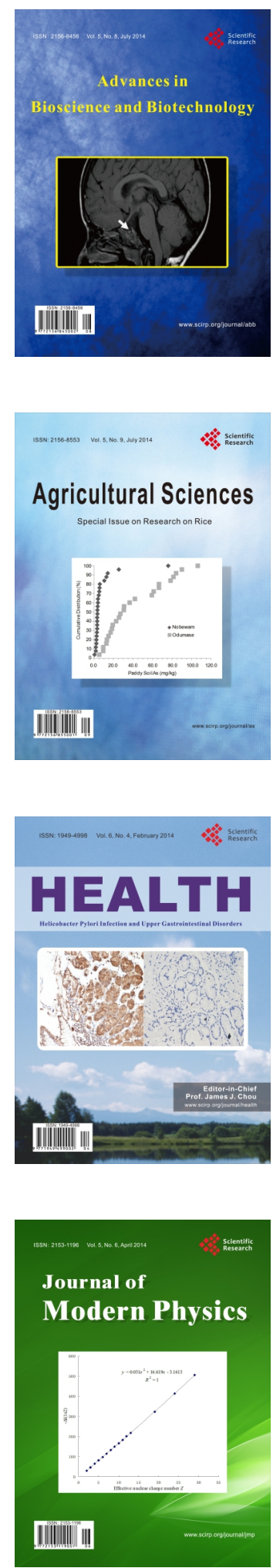
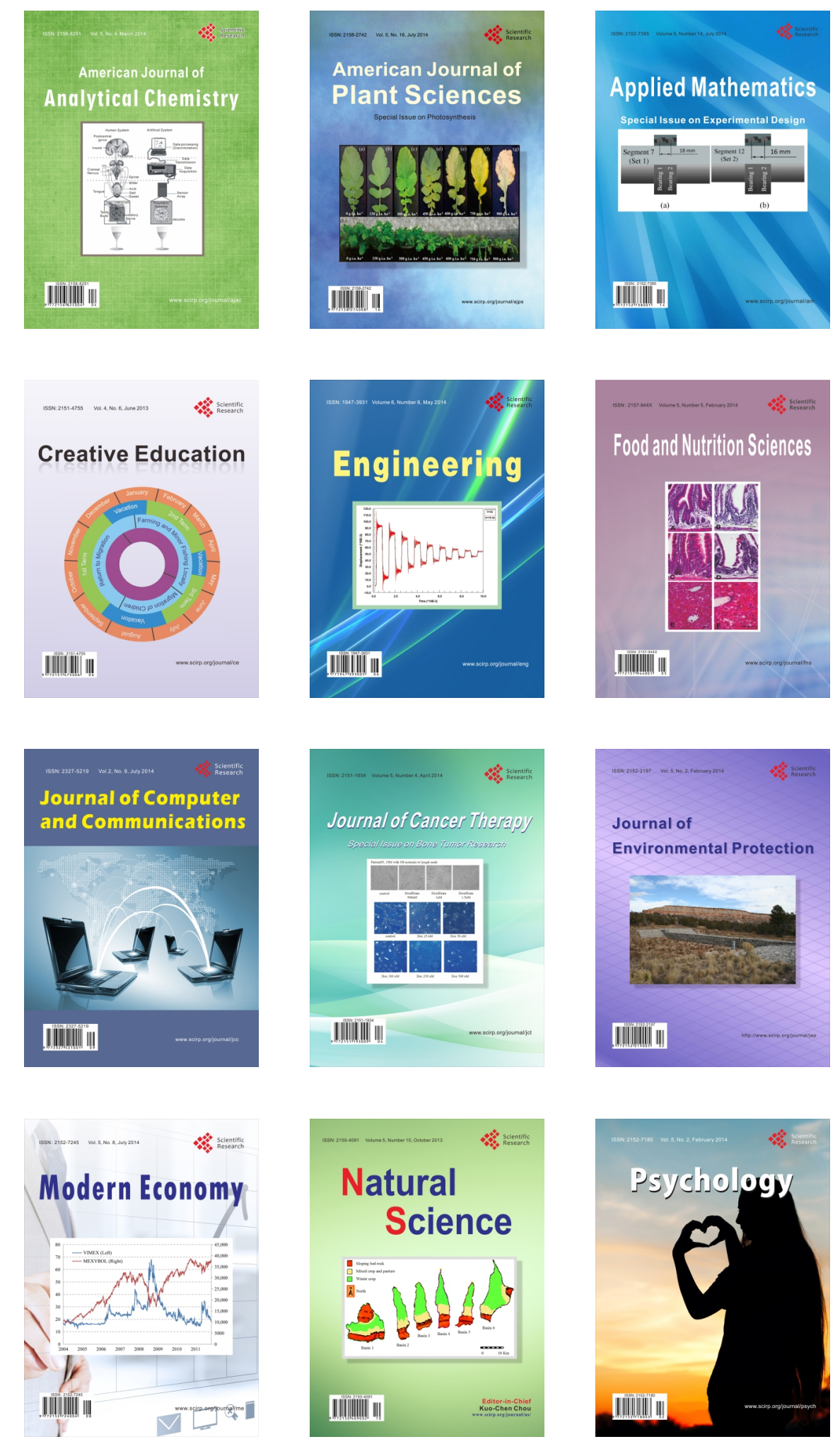